\title{
Rhizobacteria (Pseudomonas sp. SB) assist phytoremediation of oily-sludge-contaminated soil by tall fescue (Testuca arundinacea L.)
}

\author{
Wuxing Liu • Jianying Sun • Linlin Ding • \\ Yongming Luo • Mengfang Chen • Caixian Tang
}

Received: 15 January 2013 /Accepted: 5 April 2013 /Published online: 21 April 2013

(C) Springer Science+Business Media Dordrecht 2013

\begin{abstract}
Background and aims The objectives of this study were to examine the effect of direct inoculation of seeds with the rhizobacteria Pseudomonas sp. SB on the growth of tall fescue and phytodegradation efficiency in an oily-sludge-contaminated soil.

Methods SB isolated from rhizosphere soil of tall fescue was evaluated for their plant-growth-promoting characters and ability to produce biosurfactant. A pot experiment was conducted to study the effect of inoculation of SB on phytoremediation.

Results SB reduced the surface tension of culture media and produced indole acetic acid, siderophores, and 1-aminocyclopropane-1-carboxylate deaminase. Inoculation of SB increased shoot and root dry weights of
\end{abstract}

Responsible Editor: Peter Christie.

W. Liu $(\bowtie) \cdot J$. Sun $\cdot$ L. Ding $\cdot$ Y. Luo $\cdot$ M. Chen

Key Laboratory of Soil Environment and Pollution

Remediation, Institute of Soil Science,

Chinese Academy of Sciences,

Nanjing 210008, China

e-mail: liuwuxin@issas.ac.cn

Y. Luo

Institute of Coastal Zone Research,

Chinese Academy of Sciences,

Yantai 264003, China

C. Tang

Department of Agricultural Science, La Trobe University,

Melbourne Campus,

Bundoora, Victoria 3086, Australia tall fescue in oily-sludge-contaminated soil by $28 \%$ and $19 \%$, respectively. Over 120 days, the content of total petroleum hydrocarbon in soil decreased by $33.9 \%, 68.0 \%$, and $84.5 \%$, and of polycyclic aromatic hydrocarbons (PAHs) by $32.9 \%, 40.9 \%$, and $46.2 \%$, respectively, in the no-plant control, tall fescue, and tall fescue + SB treatments. Inoculation of SB also increased the activity and biodiversity of soil microbial communities in the planted treatments.

Conclusions SB could produce biosurfactant and exhibited a number of characters of plant-growthpromoting rhizobacteria. Inoculation of SB to tall fescue led to more effective remediation of oilysludge-contaminated soils.

Keywords Biosurfactant-producing bacterium . PGPR · Phytoremediation · Oily sludge

\section{Introduction}

The widespread extraction, refining, processing, transportation, and utilization of petroleum are posing an ever increasing risk of soil contamination with petroleum hydrocarbons (Tahhan et al. 2011). In addition to accidental contamination, improper disposal of oily sludge generated in oil refineries and petrochemical industries often leads to soil contamination and poses a serious threat to soil and groundwater as many of the constituents of oily sludge are carcinogenic and potent immunotoxicants (Propst et al. 1999). 
Oily-sludge-contaminated soils are currently treated using physical, chemical, and biological processes. Physical or chemical methods include incineration, chlorination, ozonation, and combustion. Many of these technologies, however, are either costly or do not result in complete removal of contaminants. On the other hand, biological treatment ("bioremediation") is widely used (Huang et al. 2005; Liu et al. 2010; Vasudevan and Rajaram 2001; Wang et al. 2012) and appears to be among the most promising methods for remediating a wide range of organic contaminants, particularly petroleum hydrocarbons though some fractions of them with high molecular weight are fairly resistant to bioremediation, requiring long periods of time for assimilation. Phytoremediation is one of bioremediation technologies. It uses plants and their associated microbes for environmental cleanup and is generally considered as an environmental friendly and gentle management option for polluted soils as it uses solar-driven biological processes to treat pollutants (Wenzel 2009). Phytoremediation can be applied at moderate contamination levels and biotoxicity or after the application of other remediation measures as a further step to degrade residual pollutants (Merkl et al. 2005). The successful application of phytoremediation of petroleum-contaminated soils has been shown in a number of studies (Gerhardt et al. 2009; Huang et al. 2005; Muratova et al. 2008). However, there are also many limitations in phytoremediation. One of the factors limiting biodegradation of oil pollutants is that many hydrocarbon compounds are less readily accessible to microorganisms in the soil due to their low aqueous solubility and strong binding/sorption onto soil matrix. Low biomass production and slow growth of the plants due to the phytotoxicity of hydrocarbons in soil also limit effective remediation (Huang et al. 2004, 2005).

One of the effective ways to increase the bioavailability of petroleum hydrocarbon pollutants in soil is using surfactants to enhance their desorption and solubilization, thereby facilitating microbial degradation (Kuyukina et al. 2005). Biosurfactants are structurally diverse group of surface-active substances produced by living cells and have desirable characteristics such as biodegradability, low toxicity, and ecological acceptability. Though most of biosurfactants are produced by microorganisms, including rhamnolipids, surfactin, sophorolipids, and so on, there are also plant-derived biosurfactants such as saponins. They can also be produced from renewable and cheaper substrates than many synthetic surfactants (Banat et al. 2000). A number of studies have been successfully carried out on soil bioremediation using biosurfactants (Cameotra and Singh 2008; Lai et al. 2009; Liu et al. 2012; Urum et al. 2003).

Successful plant growth in petroleum-contaminated soils is also critical for the optimum performance of phytoremediation. Plant-growth-promoting rhizobacteria (PGPR) have been used to enhance the tolerance of plants against toxicity through the production of plant-growthpromoting factors such as siderophores, indole-3-acetic acid (IAA), and 1-aminocyclopropane-1-carboxylate (ACC) deaminase (Glick et al. 2007). Therefore, the application of rhizobacteria with PGPR characters is a promising approach to improving the efficiency of phytoremediation. However, to the best of our knowledge, no report has been published on the utilization of biosurfactant-producing bacteria with PGPR characters to assist phytoremediation petroleum-contaminated soils.

Tall fescue (Testuca arundinacea L.) which can significantly increase the efficiency of hydrocarbon degradation in the soil (Huang et al. 2005) was used in this study. The aims of this work were (1) to characterize the biosurfactant-producing Pseudomonas sp. SB which has the characters of PGPR, (2) to determine the impact of the strain inoculation on tall fescue growth and removal rate of total petroleum hydrocarbon (TPH) and polycyclic aromatic hydrocarbons (PAHs) in an oilysludge-contaminated soil, and (3) to examine changes in the functional diversity indices of the microbial community and the acute biological toxicity of the contaminated soil after phytoremediation.

\section{Materials and methods}

\section{Soil characterization}

The oily-sludge-contaminated soil was collected from the surface layer $(0-20 \mathrm{~cm})$ in Jingmeng city, Hubei Province, China $\left(31^{\circ} 02^{\prime} \mathrm{N}, 112^{\circ} 11^{\prime} \mathrm{E}\right)$. Soil samples were air-dried, ground to pass through a $2-\mathrm{mm}$ sieve, and stored in plastic bags until use. Hydrolyzable nitrogen, cation exchange capacity (CEC), $\mathrm{pH}$, and available phosphorus and potassium were measured using standard methods (Lu 1999) before phytoremediation, and the soil had the following properties (dry-weight basis): $\mathrm{pH}$ (1:2.5 soil/water) 6.45, hydrolyzable $\mathrm{N} 558 \mathrm{mg} \mathrm{kg}^{-1}$, available P $171 \mathrm{mg} \mathrm{kg}^{-1}$, available $\mathrm{K} 174 \mathrm{mg} \mathrm{kg}^{-1}$, and cation exchange capacity $23 \mathrm{cmol} \mathrm{kg}^{-1}$. 
Bacterium and surface tension measure

Pseudomonas sp. SB was isolated from rhizosphere soil of tall fescue (Testuca arundinacea L.) grown in a petroleum-contaminated soil and stored in the laboratory. The isolated strain was inoculated into $50 \mathrm{ml}$ of the $\mathrm{LB}$ medium and incubated at $25{ }^{\circ} \mathrm{C}$ with shaking at $180 \mathrm{rpm}$ for $48 \mathrm{~h}$. The surface tension and the optical density at $600 \mathrm{~nm}$ of the culture medium were measured every $4 \mathrm{~h}$. The surface tension was measured by the ring method at $25{ }^{\circ} \mathrm{C}$ using a Model ZL-2 digital tensiometer (Boshan Tongye Analytical Instrument, Shandong, China).

ACC deaminase, phosphate solubilization, IAA, and siderophore assay

The activity of ACC deaminase of cell-free extracts was determined by estimating the amount of $\alpha$-ketobutyrate $(\alpha-\mathrm{KB})$ generated by the enzymatic hydrolysis of ACC. The amount of $\alpha-\mathrm{KB}$ was determined by comparing the absorbance at $540 \mathrm{~nm}$ of a sample to a standard curve of $\alpha$-KB (Zhang et al. 2011). Total protein was determined by the method of Bradford (1976) using bovine serum albumin as a standard. After determining the amount of protein and $\alpha-\mathrm{KB}$, the enzyme activity was expressed as molar $\alpha$-KB per milligram per hour (Jalili et al. 2009). Mineral phosphate solubilization was assayed on Pikovskaya agar plates containing insoluble tricalcium phosphate Amprayn et al. (2012). The plates were incubated at $28^{\circ} \mathrm{C}$, and development of a clear zone around the colony was evaluated at day 5 .

Bacterial IAA was measured as previously described (Glickmann and Dessaux 1995). Single bacterial colony was inoculated into the TSB medium and grown overnight with shaking at $200 \mathrm{rpm}$ in a water bath at $30^{\circ} \mathrm{C}$. The absorbance at $600 \mathrm{~nm}$ of culture was adjusted to approximately 1.2 , and $5 \mathrm{ml}$ of each culture was inoculated into $5 \mathrm{ml}$ of the DF medium [with $\left(\mathrm{NH}_{4}\right)_{2} \mathrm{SO}_{4}$ ] containing L-tryptophan $\left(200 \mu \mathrm{g} \mathrm{ml}^{-1}\right)$. The cultures were grown with shaking at $200 \mathrm{rpm}$ at $30{ }^{\circ} \mathrm{C}$ for $40 \mathrm{~h}$ (Reed et al. 2005). Siderophore secretion by the Pseudomonas sp. SB was detected by the method of Payne (1994).

\section{Pot experiment}

A pot experiment was conducted in a glasshouse with natural light. The experiment consisted of three treatments in four replicates with a fully randomized design. The treatments were (1) no-plant control, (2) tall fescue, and (3) tall fescue plus Pseudomonas sp. $\mathrm{SB}$ (tall fescue $+\mathrm{SB}$ ). Plastic pots were filled with $2.0 \mathrm{~kg}$ air-dry soil, and water content of the soil was maintained at about $80 \%$ field capacity during the experimental period. All treatments received $80 \mathrm{mg} P$ $\mathrm{kg}^{-1}$ as $\mathrm{KH}_{2} \mathrm{PO}_{4}$ before the experiment. Other nutrients were at adequate ranges and thus were not applied.

Uniform seeds of tall fescue were surface-disinfected by immersing in $0.3 \%$ sodium hypochlorite for $5 \mathrm{~min}$ and rinsing with sterilized distilled $\mathrm{H}_{2} \mathrm{O}$. An aliquot of 50 seeds were then sown in each pot of the planted treatments. For the tall fescue + SB treatment, the strain SB in the exponential phase in the LB medium were collected by centrifugation at $9,000 \times g$ for $15 \mathrm{~min}$ at $4{ }^{\circ} \mathrm{C}$, washed with sterile distilled water, and centrifuged. Bacterial inoculum was prepared by resuspending pelleted cells in sterile distilled water to obtain an inoculum density of $10^{9}$ colony-forming units (cfu) $\mathrm{ml}^{-1}$. Bacterial suspension $\left(10 \mathrm{ml} \mathrm{pot}^{-1}\right)$ was mixed with the soil before sowing seeds. Plants were harvested at day 120.

\section{TPH analysis}

Sub-samples (10 g) of freeze-dried and pulverized soil were mixed with an equal volume of anhydrous $\mathrm{Na}_{2} \mathrm{SO}_{4}$. Then the mixtures were placed in a thimble and extracted in a Soxhlet apparatus with $100 \mathrm{ml}$ tetrachloromethane for $24 \mathrm{~h}$ and analyzed by FT-IR after passing the extract through a florisil column. The TPH content of the soil before remediation is $1,851 \mathrm{mg} \mathrm{kg}^{-1}$.

\section{PAHs analysis}

An aliquot of $2 \mathrm{~g}$ freeze-dried soil samples was mixed with an equal volume of anhydrous $\mathrm{Na}_{2} \mathrm{SO}_{4}$. Then the mixtures underwent Soxhlet extraction with dichloromethane (DCM) for $24 \mathrm{~h}$. The extracts were reduced to $2 \mathrm{ml}$ using rotary evaporation followed by further concentration under a weak stream of nitrogen. The residue was dissolved in $2 \mathrm{ml}$ of cyclohexane and $0.5 \mathrm{ml}$ of the solute and extracted. The extracts were then purified by a silica gel column $(8 \mathrm{~mm} \times 220 \mathrm{~mm})$ and washed with a mixture of hexane and DCM (1:1). The first $1 \mathrm{ml}$ of elute was discarded because it contained non-polar saturated hydrocarbons and was 
less retained than PAHs by silica gel. The second 2-ml aliquot of elute was collected, dried by sparging with $\mathrm{N}_{2}$, and dissolved in $1 \mathrm{ml}$ hexane (Ping et al. 2007).

Sixteen US Environmental Protection Agency (USEPA) priority PAH compounds were identified and quantified using GC-MS. An Agilent 7890N GC system and Agilent 5795B series MSD equipped with G6500-CTC autosampler was used. The GC-MS operating conditions were as follows: DB-5 silica column $(30 \mathrm{~m} \times 0.25 \mathrm{~mm} \times 0.25 \mu \mathrm{m})$; injection temperature was set at $250{ }^{\circ} \mathrm{C}$; splitless mode. The column temperature was programmed as follows: $50{ }^{\circ} \mathrm{C}$ hold for $1 \mathrm{~min}$, rising at $25{ }^{\circ} \mathrm{C} \mathrm{min}{ }^{-1}$ to $200{ }^{\circ} \mathrm{C}$, rising at $8{ }^{\circ} \mathrm{C}$ to $280{ }^{\circ} \mathrm{C}$, rising at $1{ }^{\circ} \mathrm{C}$ to $283{ }^{\circ} \mathrm{C}$, and rising at $2{ }^{\circ} \mathrm{C}$ to $290^{\circ} \mathrm{C}$. Helium was used as the carrier gas with flow rate at $1.0 \mathrm{ml} \mathrm{min}{ }^{-1}$. Peaks was verified and quantified based on key fragment ions, retention times compared to those of external PAH standards, and/or mass spectra. The MS operating conditions were as follows: ionization voltage $70 \mathrm{eV}$, transfer line temperature $260{ }^{\circ} \mathrm{C}$, ion source $230{ }^{\circ} \mathrm{C}$, and mass scan range $m / z \quad 60-640 \mathrm{amu}$.

Microbial counts and community-level physiological profiling (CLPP) analysis

Soil samples were taken on days 60 and 120 for analyses of heterotrophic bacteria, TPH degraders and PAH degraders, and on day 120 for determination of the CLPP of the soil microbial communities. The heterotrophic bacteria were enumerated on nutrient agar plates. TPH degraders and PAH degraders were enumerated by the most-probable-number (MPN) technique (Wrenn and Venosa 1996). The CLPP of the soil microbial communities was analyzed with gram-negative (GN) microplates (BIOLOG Inc.). Aliquots of $10^{-3}$ dilutions were used to inoculate $\mathrm{GN}$ plates $\left(150 \mu \mathrm{l}\right.$ per well) and incubated at $30^{\circ} \mathrm{C}$. The plates were read every $12 \mathrm{~h}$ (OD590) over $132 \mathrm{~h}$ using a BIOLOG automated plate reader. All wells were blanked to the control well A1. For the BIOLOG data, average well color development (AWCD) was calculated as described by Garland and Mills (1991). The Shannon index, Shannon evenness, McIntosh index, McIntosh evenness, and Gini coefficient of soil microbial communities were used to measure species metabolic diversity (Harch et al. 1997; Yang and Yao 2000).
Toxicity assay

The biotoxicity of the contaminated soil before and after remediation was studied according to the methods of Płaza et al. (2005a). Briefly, DCM and dimethylsulfoxide (DMSO) were used to extract the soil. The biological toxicity of the DCM/DMSO extracts and DMSO (control) were tested based on the measurement of reduction in light emission by Photobacterium phosphoreum T3 under toxic stress. All bioassays were carried out in triplicate and light output was measured using a portable luminometer (Model DXY-2). Toxicity results were reported as the effective concentration promoting a $50 \%$ (EC50) reduction in light emitted by the bacteria.

\section{Statistical analysis}

All experiments were conducted with four replicates or otherwise specified. The data collected were analyzed statistically using SPSS 16.0 software. Duncan's multiple range tests was used to compare the means of the treatments, variability in the data was expressed as the standard deviation, and a $P<0.05$ was considered to be statistically significant.

\section{Results}

Bacterial growth and biosurfactant production

Growth curves were obtained for the strains Pseudomonas sp. SB in order to establish the relation between cell growth and surface activity of the biosurfactant in time (Fig. 1). The results showed the absorbance (growth) and surface tension of the LB medium plotted versus time for the strain. Surfactant production was directly proportional to cell growth as the surface tension decreased with increasing cell density. The lowest surface tension $\left(27.3 \mathrm{mN} \mathrm{m}^{-1}\right)$ and highest absorbance (1.59) was obtained at $16 \mathrm{~h}$. Therefore, $16 \mathrm{~h}$ incubation is sufficient for surfactant production and cell growth in the following experiments.

Plant-growth-promotion features of Pseudomonas sp. SB

Pseudomonas sp. SB was found to exhibit a number of traits which are important for plant-growth-promoting activity. The production of ACC deaminase was 


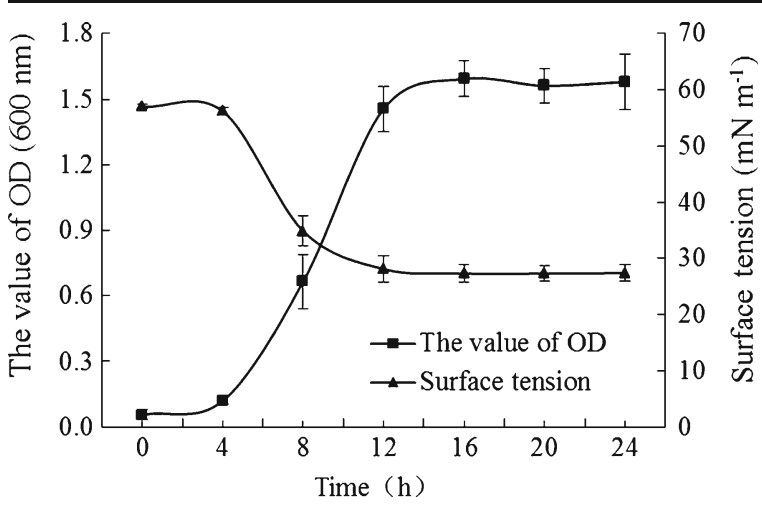

Fig. 1 Growth and biosurfactant production curves of Pseudomonas sp. SB. Error bars: \pm 1 standard deviation $(n=3)$

$2.04 \mathrm{M} \alpha-\mathrm{KB} \mathrm{mg}^{-1} \mathrm{~h}^{-1}$ in the DF medium. The strain also had the capacity to produce IAA $\left(16.0 \mathrm{mg}^{-1}\right)$ in the LB medium when the medium was supplemented with L-tryptophan. Orange halos around the colonies of SB on the blue agar were formed, indicating siderophore excretion of the strain. Clear zone around the colony of the strain appeared in the SRSM agar plate after 5 days, indicating that the strain was able to solubilize P (Jin-Hee et al. 2011).

Plant growth

The inoculation of Pseudomonas sp. SB improved the growth of tall fescue. It increased shoot and root dry weights by $28 \%$ and $19 \%$, respectively, by the end of the experiment (Table 2).

\section{Degradation of TPH and PAHs}

The TPH contents of the soil after 120 days are shown in Table 1 . The TPH decreased by $33.8 \%, 68.0 \%$, and $84.5 \%$ in non-planted control, tall fescue, and tall fescue $+\mathrm{SB}$ treatments, respectively. The content of TPH was significantly lower $(P<0.05)$ in two treatments with plants than the control, and the inoculation of BS further decreased TPH contents.

Sixteen USEPA PAHs were detected in the initial soil (Table 2). After 120 days, total PAHs decreased by $31.7 \%, 40.7 \%$, and $46.2 \%$ in the control, tall fescue, and tall fescue $+\mathrm{SB}$ treatments, respectively. Compared with the tall fescue treatment, the inoculation of BS further decreased the contents of total PAHs and individual PAHs with high molecular weights (HMW) (five to six rings) such as benzo[k]fluoranthene,
Table 1 Effect of growing tall fescue for 120 days and inoculation of Pseudomonas sp. SB on plant biomass and concentration of total petroleum hydrocarbon (TPH) in soil

\begin{tabular}{lcll}
\hline Treatments & $\begin{array}{l}\text { Shoot dry } \\
\text { weight }(\mathrm{g})\end{array}$ & $\begin{array}{l}\text { Root dry } \\
\text { weight }(\mathrm{g})\end{array}$ & $\begin{array}{l}\mathrm{TPH} \\
\left(\mathrm{mg} \mathrm{kg}^{-1}\right)\end{array}$ \\
\hline No-plant control & - & - & $1,224 \pm 16 \mathrm{a}$ \\
Tall fescue & $9.64 \pm 0.50 \mathrm{~b}$ & $2.29 \pm 0.27 \mathrm{~b}$ & $593 \pm 63 \mathrm{~b}$ \\
Tall fescue + SB & $13.38 \pm 1.34 \mathrm{a}$ & $2.84 \pm 0.19 \mathrm{a}$ & $286 \pm 22 \mathrm{c}$ \\
\hline
\end{tabular}

The data represent the mean \pm standard deviation of four replicates, and data followed by different letters indicate a significant difference at $p<0.05$ according to Duncan's multiple range tests

dibenz $[a h]$ anthracene, and benzo[ghi]perylene. For example, the removal efficiency of benzo $[a]$ pyrene, a strongly carcinogenic compound, was $43.7 \%, 43.7 \%$, and $61.3 \%$ in the soil of the control, tall fescue, and tall fescue + SB treatments, respectively.

\section{Microbial populations}

To reveal the treatment effects on microbial communities in the soil, heterotrophic bacteria, TPH degraders, and PAH degraders were quantified at days 60 and 120. The counts of heterotrophic bacteria, TPH degraders, and PAH degraders were all the highest in the tall fescue + SB treatment and lowest in the noplant control at day 60. Heterotrophic bacteria showed the same trend at day 120, but the counts of TPH and PAHs degraders decreased over time and were lower in the plant treatments than in the control at day 120 (Table 3).

CLPP of the sludge microbial communities

AWCD and diversity index were analyzed using BIOLOG data to detect treatment difference in microbial communities. The activity of soil microbial communities in the soil evaluated by AWCD increased over time and was highest in the tall fescue + SB treatment and lowest in the controls (Fig. 2). The absorbance of each well in the BIOLOG plates at $72 \mathrm{~h}$ was used to calculate diversity indices of the microbial community (Table 4). The Shannon index, Gini coefficient, and McIntosh evenness were significantly higher in the planted treatments than in the control. The inoculation of SB further increased the Shannon evenness, McIntosh Index, and Gini coefficient. 
Table 2 Removal of polycyclic aromatic hydrocarbon (PAHs) after 120 days of growing tall fescue with or without inoculation of Pseudomonas sp. SB

\begin{tabular}{|c|c|c|c|c|c|c|c|}
\hline \multirow[t]{2}{*}{ PAHs } & \multirow{2}{*}{$\begin{array}{l}\text { Initial } \\
\left(\mu \mathrm{g} \mathrm{kg}^{-1} \text { soil) }\right.\end{array}$} & \multicolumn{2}{|c|}{ No-plant control } & \multicolumn{2}{|l|}{ Tall fescue } & \multicolumn{2}{|c|}{ Tall fescue + SB } \\
\hline & & $\begin{array}{l}\text { Concentration } \\
\left(\mu \mathrm{g} \mathrm{kg}^{-1} \text { soil }\right)\end{array}$ & $\%$ Removal $^{\mathrm{a}}$ & $\begin{array}{l}\text { Concentration } \\
\left(\mu \mathrm{g} \mathrm{kg}^{-1} \text { soil) }\right.\end{array}$ & \% Removal & $\begin{array}{l}\text { Concentration } \\
\left(\mu \mathrm{g} \mathrm{kg}^{-1} \text { soil) }\right.\end{array}$ & $\%$ Removal \\
\hline Naphthalene & $747 \pm 31 \mathrm{a}$ & $329 \pm 26 c$ & $55.9 \pm 3.5$ & $176 \pm 7 b$ & $76.4 \pm 0.9$ & $91 \pm 2 d$ & $87.9 \pm 0.2$ \\
\hline Acenaphthylene & $106 \pm 14 \mathrm{a}$ & $61 \pm 5 b c$ & $42.1 \pm 4.2$ & $51 \pm 1 b$ & $51.4 \pm 0.5$ & $44 \pm 6 c$ & $58.4 \pm 5.3$ \\
\hline Acenaphthene & $150 \pm 22 \mathrm{a}$ & $94 \pm 7 b$ & $37.5 \pm 4.6$ & $80 \pm 1 b$ & $46.9 \pm 0.5$ & $73 \pm 8 b$ & $51.8 \pm 5.3$ \\
\hline Fluorene & $505 \pm 17 \mathrm{a}$ & $362 \pm 20 \mathrm{~b}$ & $28.3 \pm 4.0$ & $292 \pm 18 \mathrm{c}$ & $42.2 \pm 3.5$ & $292 \pm 27 \mathrm{c}$ & $42.2 \pm 5.3$ \\
\hline Phenanthrene & $288 \pm 24 a$ & $299 \pm 21 b c$ & 0 & $255 \pm 6 c$ & $11.7 \pm 2.0$ & $264 \pm 17 b c$ & $8.7 \pm 6.0$ \\
\hline Anthracene & $93 \pm 7 \mathrm{a}$ & $51 \pm 9 b$ & $44.8 \pm 10.0$ & $57 \pm 4 b$ & $38.5 \pm 4.4$ & $59 \pm 4 b$ & $36.4 \pm 4.1$ \\
\hline Fluoranthene & $157 \pm 8 \mathrm{a}$ & $118 \pm 9 b$ & $25.3 \pm 5.4$ & $119 \pm 3 b$ & $24.5 \pm 2.0$ & $114 \pm 3 b$ & $27.3 \pm 2.0$ \\
\hline Pyrene & $185 \pm 13 \mathrm{a}$ & $143 \pm 5 b$ & $22.8 \pm 2.6$ & $141 \pm 8 b$ & $23.6 \pm 4.0$ & $117 \pm 6 c$ & $36.7 \pm 3.1$ \\
\hline Benz $[a]$ anthracene & $151 \pm 12 \mathrm{a}$ & $96 \pm 13 b$ & $36.3 \pm 8.8$ & $94 \pm 4 b$ & $37.7 \pm 3.0$ & $84 \pm 2 b$ & $44.5 \pm 1.2$ \\
\hline Chrysene & $824 \pm 18 \mathrm{a}$ & $442 \pm 40 \mathrm{~b}$ & $46.4 \pm 4.9$ & $361 \pm 9 c$ & $56.2 \pm 1.2$ & $301 \pm 11 d$ & $63.5 \pm 1.3$ \\
\hline Benzo $[b]$ fluoranthene & $612 \pm 15 \mathrm{a}$ & $232 \pm 23 b$ & $62.1 \pm 3.9$ & $190 \pm 22 b$ & $69.0 \pm 3.6$ & $250 \pm 84 b$ & $59.2 \pm 13.7$ \\
\hline Benzo $[k]$ fluoranthene & $411 \pm 14 \mathrm{a}$ & $175 \pm 6 b$ & $57.5 \pm 1.3$ & $171 \pm 5 b$ & $58.5 \pm 1.1$ & $104 \pm 4 c$ & $74.7 \pm 1.0$ \\
\hline Benz $[a]$ pyrene & $426 \pm 6 a$ & $240 \pm 5 b$ & $43.7 \pm 1.1$ & $240 \pm 6 b$ & $43.7 \pm 1.4$ & $165 \pm 3 c$ & $61.3 \pm 0.8$ \\
\hline Indeno $[123-c d]$ pyrene & $357 \pm 23 a$ & $227 \pm 17 b$ & $36.5 \pm 4.8$ & $160 \pm 23 c$ & $55.1 \pm 6.3$ & $135 \pm 8 \mathrm{c}$ & $62.2 \pm 2.2$ \\
\hline Dibenz $[a h]$ anthracene & $7,599 \pm 115 \mathrm{a}$ & $5,614 \pm 159 b$ & $26.1 \pm 2.1$ & $5,066 \pm 271 \mathrm{c}$ & $33.3 \pm 3.6$ & $4,741 \pm 90 \mathrm{c}$ & $37.6 \pm 1.2$ \\
\hline Benzo $[g h i]$ perylene & $339 \pm 20 \mathrm{a}$ & $203 \pm 9 b$ & $40.2 \pm 2.7$ & $202 \pm 4 b$ & $40.4 \pm 1.1$ & $130 \pm 3 c$ & $61.6 .6 \pm 0.8$ \\
\hline Total & $12,950 \pm 65 \mathrm{a}$ & $8,684 \pm 101 b$ & $32.9 \pm 0.8$ & $7,655 \pm 331 \mathrm{c}$ & $40.9 \pm 2.5$ & $6,964 \pm 179 d$ & $46.2 \pm 1.4$ \\
\hline
\end{tabular}

The data represent the mean \pm standard deviation of four replicates, and data followed by different letters in the same row indicate a significant difference at $p<0.05$ according to Duncan's multiple range tests

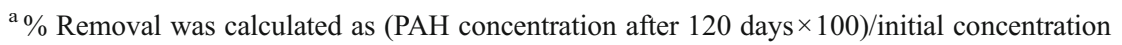

\section{Biotoxicity assay}

Biotoxicity of the soil was determined before and after phytoremediation by $P$. phosphoreum $\mathrm{T}_{3}$. EC50 values were ranked as follows: Before remediation (Before Rem) $<$ No-plant control $<$ Tall fescue $<$ Tall fescue + SB (Fig. 3), indicating that both growing tall fescue and inoculation of BS decreased the biotoxicity of the soil.

Table 3 Heterotrophic bacteria, TPH degraders, and PAH degraders in the soil after growing tall fescue for 60 and 120 days with or without inoculation of Pseudomonas sp. SB

\begin{tabular}{|c|c|c|c|c|c|c|}
\hline & \multicolumn{4}{|l|}{60 Days } & \multicolumn{2}{|l|}{120 Days } \\
\hline & Control & Tall fescue & Tall fescue + SB & Control & Tall fescue & Tall fescue + SB \\
\hline $\begin{array}{l}\text { Heterotrophic bacteria } \\
\left(\log \text { cfu }^{-1} \text { dry soil }\right)\end{array}$ & $8.28 \pm 0.06 \mathrm{~b}$ & $8.49 \pm 0.04 \mathrm{a}$ & $8.57 \pm 0.05 \mathrm{a}$ & $8.27 \pm 0.04 c$ & $8.44 \pm 0.05 b$ & $8.65 \pm 0.03 a$ \\
\hline $\begin{array}{l}\text { TPH degraders } \\
\quad\left(\log \text { MPN g }{ }^{-1} \text { dry soil) }\right.\end{array}$ & $4.98 \pm 0.04 \mathrm{c}$ & $6.22 \pm 0.09 b$ & $6.42 \pm 0.08 \mathrm{a}$ & $5.2 \pm 0.17 \mathrm{a}$ & $4.50 \pm 0.13 b$ & $4.44 \pm 0.07 \mathrm{~b}$ \\
\hline $\begin{array}{l}\text { PAH degraders } \\
\text { (log MPN g }{ }^{-1} \text { dry soil) }\end{array}$ & $4.82 \pm 0.05 b$ & $5.27 \pm 0.12 \mathrm{a}$ & $5.43 \pm 0.06 \mathrm{a}$ & $4.30 \pm 0.30 \mathrm{a}$ & $3.76 \pm 0.05 b$ & $3.69 \pm 0.17 b$ \\
\hline
\end{tabular}

The data represent the mean \pm standard deviation of four replicates, and data followed by different letters in the same row at the same sampling day indicate a significant difference at $p<0.05$ according to Duncan's multiple range tests 


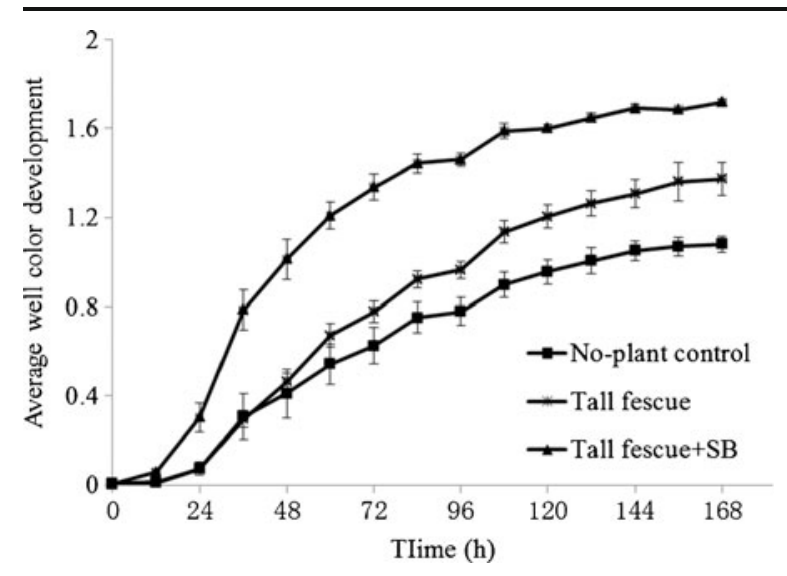

Fig. 2 Changes in average well color development (AWCD) of soil microbial community during incubation. Error bars: \pm 1 standard deviation $(n=4)$

\section{Discussion}

Mass transfer from adsorbed or insoluble phases to the aqueous phase is considered to be the rate-limiting step in biodegradation of organic contaminants because the compounds must be released to the aqueous phase prior to entering the microbial cell and subsequent intracellular transformation by the necessary catabolic enzymes (Dean et al. 2001). Compounds present in oily sludge are inherited from petroleum hydrocarbons, and most of them are insoluble. Furthermore, oily sludge undergoes several aging and weathering processes that eventually lead to the compounds having low water solubility. As shown in Table 2, the HMW PAHs (five- and six-ring PAHs) with low water solubility accounted for $75 \%$ of total PAHs in the oily contaminated soil used in this experiment. There are several reports on improving oily sludge degradation by addition of biosurfactant or chemical surfactant to increase the bioavailability of

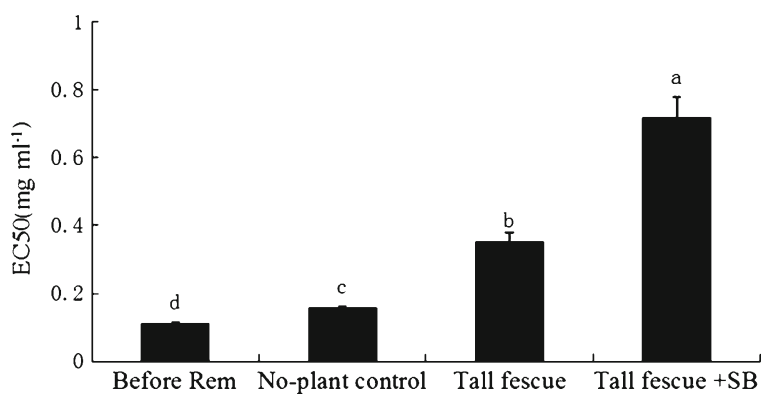

Fig. 3 Biotoxicity of the soil under different treatments. Error bars: \pm 1 standard deviation $(n=4)$. Different letters indicate a significant difference at $p<0.05$ according to Duncan's multiple range tests

the hydrocarbons (Ahn et al. 2010; Benincasa 2007; Cameotra and Singh 2008; Lai et al. 2009). However, the effect of inoculating biosurfactant-producing bacteria which can produce surfactants successively is relatively less studied.

This study showed that Strain SB produced the biosurfactant that reduces the surface tension of medium to $27.3 \mathrm{mN} \mathrm{m}^{-1}$. The biosurfacant is expected to enhance desorption of TPHs and PAHs and increased their removal from the soil. It was evident that SB inoculation significantly $(P<0.05)$ increased the removal of TPHs and PAHs in the sludge-contaminated soil. For HMW PAHs such as benzo[ghi]perylene, benz $[a]$ pyrene, and benzo $[k]$ fluoranthene, their removal rates were $21.2 \%$, $17.6 \%$, and $16.3 \%$ higher in the BS inoculated treatment than in the tall fescue alone treatment, respectively. These PAHs all have large $K_{\text {ow }}$ (above 6.0) and low water solubility. The bioavailability could be the ratedetermining factor for their degradation. One possible reason why biosurfactant-producing bacteria enhanced the removal of TPHs and PAHs is that the inoculation could increase the rate of solubilization and desorption of TPHs and PAHs by enhancing the rate of mass

Table 4 Functional diversity indices of microbial community in soils of no-plant control and after 120 days of growing tall fescue with or without inoculation of Pseudomonas sp. SB

\begin{tabular}{llllll}
\hline Treatments & Shannon index & Shannon evenness & Gini coefficient & McIntosh index & McIntosh evenness \\
\hline No-plant control & $3.971 \pm 0.015 \mathrm{~b}$ & $0.901 \pm 0.007 \mathrm{~b}$ & $0.978 \pm 0.001 \mathrm{c}$ & $11.211 \pm 2.463 \mathrm{~b}$ & $0.955 \pm 0.004 \mathrm{~b}$ \\
Tall fescue & $4.193 \pm 0.071 \mathrm{a}$ & $0.912 \pm 0.014 \mathrm{~b}$ & $0.982 \pm 0.001 \mathrm{~b}$ & $11.972 \pm 0.439 \mathrm{~b}$ & $0.973 \pm 0.006 \mathrm{a}$ \\
Tall fescue + SB & $4.322 \pm 0.040 \mathrm{a}$ & $0.959 \pm 0.004 \mathrm{a}$ & $0.986 \pm 0.001 \mathrm{a}$ & $16.782 \pm 1.342 \mathrm{a}$ & $0.984 \pm 0.002 \mathrm{a}$ \\
\hline
\end{tabular}

The data represent the mean \pm standard deviation of four replicates, and data followed by different letters in the same column indicate a significant difference at $p<0.05$ according to Duncan's multiple range tests 
transfer from adsorbed phases to soil solution (Juhasz and Naidu 2000).

Apart from the produced biosurfactant, Pseudomonas sp. SB used in this experiment also exhibited a number of characters of PGPR and improved the development of the root and shoot system of tall fescue. It produced IAA and siderophore, and had the P-solubilization ability. Especially, the bacteria with ACC-deaminase activity metabolize ACC (an immediate precursor of ethylene in plants) into $\alpha$-ketobutyric acid and ammonia, thus regulating the biosynthesis of ethylene and promoting plant growth.

The degradation of most hydrocarbons is believed to enhance through a rhizosphere effect. Plants exude organic compounds through their roots, which increase the density, diversity, and activity of specific microorganisms which in turn degrade hydrocarbons in the surrounding rhizosphere (Phillips et al. 2006). Hence, extensive root growth is a prerequisite of maximizing the effectiveness of phytoremediation processes. Reduced root growth in contaminated soils might be owing to production of ethylene induced by toxicity stress (Arshad et al. 2007). Huang et al. (2004; 2005) demonstrated that biomass accumulation and root growth of tall fescue were severely decreased by TPHs in soil, although tall fescue is relatively tolerant of organic contaminants. Merkl et al. (2005) also showed that root biomass was positively correlated with phytoremediation activity in a hydrocarboncontaminated soil.

In phytoremediation, hydrocarbons are degraded mainly by soil microbial communities. Therefore, the phytoremediation potential can be characterized by enumerating cultivable soil heterotrophic and pollutant-degrading bacteria in the rhizosphere (Muratova et al. 2008). This present study showed that tall fescue planting and SB inoculation promoted TPH and $\mathrm{PAH}$ degraders at 60 days, although the TPH and PAHs degraders were lower than that of control at 120 days (Table 3). The heterotrophic bacterial counts in the two planted treatments were always higher than in the control plot throughout the experiment (Table 3). The reason might be that most of the TPH and PAHs were degraded in two planted treatments and their concentration was very low and hard to support the degraders' growth at the end of the experiment.

Wuensche et al. (1995) demonstrated that substrate utilization patterns as recorded with the BIOLOG system are suitable for rapidly assessing the dynamics of autochthonous communities and evaluating their biodegradative potential in soil. The highest activity of soil microbial communities evaluated by AWCD in the tall fescue + SB treatment indicates that tall fescue and Pseudomonas sp. SB inoculation had important influences on the microbial activity.

There were also similar effects of growing tall fescue and SB inoculation on microbial metabolic diversity reflected by Shannon index, McIntosh index, and Gini coefficient. The Shannon index provides the information on the distribution of $\mathrm{C}$ source utilization by microbial communities and potential metabolic diversity of the communities while the McIntosh index provides information on species richness based on the number of species and their abundances. Gini coefficient quantifies the inequality of use of carbon sources (richness and evenness) (Harch et al. 1997). Thus, it can be concluded that phytoremediation not only decreased TPH content but also increased microbial activity and community diversity in this oily-sludgecontaminated soil. It must be emphasized that CLPP is not a culture-independent method and is somewhat biased towards fast-growing and easily cultivable species (Smalla et al. 1998).

Petroleum contains hundreds of individual compounds with varying degrees of toxicity, mutagenicity, and carcinogenicity, and its composition varies with sites and source strata (Liu et al. 2009). Therefore, ecotoxicity bioassays should be used as supplementary tools for monitoring the remediating effectiveness of petroleum-contaminated sites (Płaza et al. 2008; Płaza et al. 2005b). In this study, the toxicities of the soil as a function of petroleum biodegradation activity were also determined. P. phosphoreum T3 was used to test the biotoxicity of the oily sludge before and after bioremediation. The EC50 of the soils increased by $41 \%$, $218 \%$, and $550 \%$ in the control, tall fescue, and tall fescue + SB treatments, respectively, at the end of the experiment. Clearly, the EC50 of the SB-inoculated treatment was the highest, indicating that the soil of this treatment had the lowest toxicity. This ecotoxicity decrease of the soils might be due to the efficient conversion of the toxic raw-petroleum material to less or non-toxic intermediates and by-products during biodegradation (Płaza et al. 2008).

\section{Conclusion}

In this study, the biosurfactant-producing strain Pseudomonas sp. SB was isolated from rhizosphere 
of tall fescue grown in a petroleum-contaminated soil. This strain can produce biosurfactants thereby decreasing the surface tension of the culture medium to $27.3 \mathrm{mN} \mathrm{m}^{-1}$ after $16 \mathrm{~h}$ of growth. This strain also produced IAA, siderophores, and ACC deaminase. The inoculation of the SB strain promoted the growth of tall fescue and significantly enhanced the degradation of TPH and PAHs. It also increased the microbial activity and diversity in the soil. Furthermore, the inoculation of the SB markedly decreased the biotoxicity of the contaminated soil. Thus biosurfactant-producing Pseudomonas sp. SB which has the characters of PGPR may be a suitable bioinoculant to assist phytoremediation of oily-sludgecontaminated soils, but validation under field conditions is needed.

Acknowledgments We thank the National Natural Science Foundation of China (41001182), Jiangsu Provincial Natural Science Foundation of China (BK2012891), and the Environmental Protection Public Welfare Special Fund for Scientific Research (201009015) for financial support.

\section{References}

Ahn CK, Woo SH, Park JM (2010) Surface solubilization of phenanthrene by surfactant sorbed on soils with different organic matter contents. J Hazard Mater 177:799-806

Amprayn K, Rose MT, Kecskés M, Pereg L, Nguyen HT, Kennedy IR (2012) Plant growth promoting characteristics of soil yeast (Candida tropicalis HY) and its effectiveness for promoting rice growth. Appl Soil Ecol 61:295-299

Arshad M, Saleem M, Hussain S (2007) Perspectives of bacterial ACC deaminase in phytoremediation. Trends Biotechnol 25:356-362

Banat IM, Makkar RS, Cameotra SS (2000) Potential commercial applications of microbial surfactants. Appl Microbiol Biotechnol 53:495-508

Benincasa M (2007) Rhamnolipid produced from agroindustrial wastes enhances hydrocarbon biodegradation in contaminated soil. Curr Microbiol 54:445-449

Bradford MM (1976) A rapid and sensitive method for the quantitation of microgram quantities of protein utilizing the principle of protein-dye binding. Anal Biochem 72:248-254

Cameotra SS, Singh P (2008) Bioremediation of oil sludge using crude biosurfactants. Int Biodeterior Biodegrad 62:274-280

Dean SM, Jin Y, Cha DK, Wilson SV, Radosevich M (2001) Phenanthrene degradation in soils co-inoculated with phenanthrene-degrading and biosurfactant-producing bacteria. J Environ Qual 30:1126-1133

Garland JL, Mills AL (1991) Classification and characterization of heterotrophic microbial communities on the basis of patterns of community-level sole-carbon-source utilization. Appl Environ Microbiol 57:2351-2359

Gerhardt KE, Huang XD, Glick BR, Greenberg BM (2009) Phytoremediation and rhizoremediation of organic soil contaminants: potential and challenges. Plant Sci 176:20-30

Glick BR, Cheng Z, Czarny J, Duan J (2007) Promotion of plant growth by ACC deaminase-producing soil bacteria. Eur J Plant Pathol 119:329-339

Glickmann E, Dessaux Y (1995) A critical examination of the specificity of the salkowski reagent for indolic compounds produced by phytopathogenic bacteria. Appl Environ Microbiol 61:793-796

Harch BD, Correll RL, Meech W, Kirkby CA, Pankhurst CE (1997) Using the Gini coefficient with BIOLOG substrate utilisation data to provide an alternative quantitative measure for comparing bacterial soil communities. J Microbiol Methods 30:91-101

Huang XD, El-Alawi Y, Penrose DM, Glick BR, Greenberg BM (2004) Responses of three grass species to creosote during phytoremediation. Environ Pollut 130:453-463

Huang XD, El-Alawi Y, Gurska J, Glick BR, Greenberg BM (2005) A multi-process phytoremediation system for decontamination of persistent total petroleum hydrocarbons (TPHs) from soils. Microchem J 81:139-147

Jalili F, Khavazi K, Pazira E, Nejati A, Rahmani HA, Sadaghiani HR, Miransari M (2009) Isolation and characterization of ACC deaminase-producing fluorescent pseudomonads, to alleviate salinity stress on canola (Brassica napus L.) growth. J Plant Physiol 166:667-674

Jin-Hee P, Nanthi B, Mallavarapu M, Ravi N (2011) Isolation and characterization of phosphate solubilizing bacteria from phosphate amended and lead contaminated soils. J Hazard Mater 185:829-836

Juhasz AL, Naidu R (2000) Bioremediation of high molecular weight polycyclic aromatic hydrocarbons: a review of the microbial degradation of benzo[a]pyrene. Int Biodeterior Biodegrad 45:57-88

Kuyukina MS, Ivshina IB, Makarov SO, Litvinenko LV, Cunningham CJ, Philp JC (2005) Effect of biosurfactants on crude oil desorption and mobilization in a soil system. Environ Int 31:155-161

Lai CC, Huang Y, Wei YH, Chang JS (2009) Biosurfactantenhanced removal of total petroleum hydrocarbons from contaminated soil. J Hazard Mater 167:609-614

Liu WX, Luo YM, Teng Y, Li ZG, Christie P (2009) Prepared bed bioremediation of oily sludge in an oilfield in northern China. J Hazard Mater 161:479-484

Liu WX, Luo YM, Teng Y, Li ZG, Ma L (2010) Bioremediation of oily sludge-contaminated soil by stimulating indigenous microbes. Environ Geochem Heal 32:23-29

Liu WX, Wang XB, Wu LH, Chen MF, Tu C, Luo YM, Christie $P$ (2012) Isolation, identification and characterization of Bacillus amyloliquefaciens BZ-6, a bacterial isolate for enhancing oil recovery from oily sludge. Chemosphere $87: 1105-1110$

Lu RK (1999) Analytical methods of soil agricultural chemistry. China Agricultural Science and Technology Press, Beijing (in Chinese)

Merkl N, Schultze-Kraft R, Infante C (2005) Assessment of tropical grasses and legumes for phytoremediation of petroleum-contaminated soils. Water Air Soil Pollut 165:195-209 
Muratova AY, Dmitrieva TV, Panchenko LV, Turkovskaya OV (2008) Phytoremediation of oil-sludge-contaminated soil. Int J Phytoremediation 10:486-502

Payne SM (1994) Detection, isolation, and characterization of siderophores. Methods Enzymol 235:329-344

Phillips LA, Greer CW, Germida JJ (2006) Culture-based and culture-independent assessment of the impact of mixed and single plant treatments on rhizosphere microbial communities in hydrocarbon contaminated flare-pit soil. Soil Biol Biochem 38:2823-2833

Ping LF, Luo YM, Zhang HB, Li QB, Wu LH (2007) Distribution of polycyclic aromatic hydrocarbons in thirty typical soil profiles in the Yangtze River Delta region, east China. Environ Pollut 147:358-365

Plaza G, Jangid K, Lukasik K, Nalecz-Jawecki G, Berry C, Brigmon R (2008) Reduction of petroleum hydrocarbons and toxicity in refinery wastewater by bioremediation. Bull Environ Contam Toxicol 81:329-333

Płaza G, Nałecz-Jawecki G, Ulfig K, Brigmon RL (2005a) The application of bioassays as indicators of petroleumcontaminated soil remediation. Chemosphere 59:289-296

Płaza G, Nałecz-Jawecki G, Ulfig K, Brigmon RL (2005b) Assessment of genotoxic activity of petroleum hydrocarbonbioremediated soil. Ecotoxicol Environ Saf 62:415-420

Propst TL, Lochmiller RL, Qualls CW Jr, McBee K (1999) In situ (mesocosm) assessment of immunotoxicity risks to small mammals inhabiting petrochemical waste sites. Chemosphere 38:1049-1067

Reed MLE, Warner B, Glick B (2005) Plant growth-promoting bacteria facilitate the growth of the common reed Phragmites australis in the presence of copper or polycyclic aromatic hydrocarbons. Curr Microbiol 51:425-429

Smalla K, Wachtendorf U, Heuer H, Liu W, Forney L (1998) Analysis of BIOLOG GN substrate utilization patterns by microbial communities. Appl Environ Microbiol 64:12201225
Tahhan RA, Ammari TG, Goussous SJ, Al-Shdaifat HI (2011) Enhancing the biodegradation of total petroleum hydrocarbons in oily sludge by a modified bioaugmentation strategy. Int Biodeterior Biodegrad 65:130-134

Urum K, Pekdemir T, Gopur M (2003) Optimum conditions for washing of crude oil-contaminated soil with biosurfactant solutions. Process Saf Environ Prot 81:203-209

Vasudevan N, Rajaram P (2001) Bioremediation of oil sludgecontaminated soil. Environ Int 26:409-411

Wang X, Wang Q, Wang S, Li F, Guo G (2012) Effect of biostimulation on community level physiological profiles of microorganisms in field-scale biopiles composed of aged oil sludge. Bioresour Technol 111:308315

Wenzel W (2009) Rhizosphere processes and management in plant-assisted bioremediation (phytoremediation) of soils. Plant Soil 321:385-408

Wrenn BA, Venosa AD (1996) Selective enumeration of aromatic and aliphatic hydrocarbon degrading bacteria by a most-probable-number procedure. Can J Microbiol 42:252-258

Wunsche L, Bruggemann L, Babel W (1995) Determination of substrate utilization patterns of soil microbial communities: an approach to assess population changes after hydrocarbon pollution. FEMS Microbiol Ecol 17:295-305

Yang YH, Yao J (2000) Effect of pesticide pollution against functional microbial diversity in soil (in Chinese). J Microbiol 20:23-25

Zhang Y, He L, Chen Z, Wang Q, Qian M, Sheng X (2011) Characterization of ACC deaminase-producing endophytic bacteria isolated from copper-tolerant plants and their potential in promoting the growth and copper accumulation of Brassica napus. Chemosphere 83:57-62 